\title{
Investigation on Thermophysical Properties of Thymic Cell Cultures Exposed to Electromagnetic Fields
}

\author{
Federico Rossi ${ }^{1} \&$ Andrea Nicolini ${ }^{1}$ \\ ${ }^{1}$ University of Perugia, CIRIAF, Perugia, Italy \\ Correspondence: Andrea Nicolini, University of Perugia, CIRIAF, Via G.Duranti 67, Perugia 06125, Italy. Tel: \\ 39-75-585-3714. E-mail: Nicolini.unipg@ciriaf.it
}

Received: August 1, 2012 Accepted: August 27, 2012 Online Published: September 18, 2012

doi:10.5539/ep.v2n1p11 URL: http://dx.doi.org/10.5539/ep.v2n1p11

\begin{abstract}
The paper deals with an investigation of the possible effects of RF electromagnetic fields towards the environment and human health. An experimental facility was designed and built and in vitro experiments were carried out on thymic cell cultures. They were exposed for three and six hours to $144 \mathrm{MHz}$ RF electromagnetic fields. The effects were analysed in terms of the possible variation of their thermophysical properties (density, viscosity, specific heat). Results showed that the tested configuration does not induce alterations of the thermophysical properties of the tested cell cultures.
\end{abstract}

Keywords: thyme, electromagnetic fields, experimental data, specific heat, density, viscosity

\section{Introduction}

Electromagnetic pollution has been becoming a relevant problem for environmental policies for many years, especially in terms of its tight connection with human health (National Council on Radiation Protection and Measurements, 1986; World Health Organization [WHO], 1993). NIR (Non Ionizing Radiation) interaction with environment and man is one of the most interesting research fields for the world scientific community. Human exposure to electromagnetic fields, depending on their intensity, frequency and duration, was studied in terms of many possible effects. The effects of electromagnetic fields on living systems were studied both in vivo and in vitro in a wide range of organisms, cells and tissues (Heinrich, Thomas, Heumann, Von Kries, \& Radon, 2011; Hocking, Gordon, Grain, \& Hatfield, 1996; Khalid et al., 2011; Rosai \& Sobin, 1999; Thomas, Heinrich, Von Kries, \& Radon, 2010). However, the action of electromagnetic fields is not yet clearly defined and the obtained results are often contradictory. For example, it was found that cellular phones may give problems in iliac bones (Atay et al., 2009). Also pulsed electromagnetic fields were studied (both for ELF and RF fields) obtaining low or negligible alterations: changes in the distribution of cytoskeletal proteins of osteoblasts (Noriega-Luna, Sabanero, Sosa, \& Avila-Rodriguez, 2011), increased phytohaemagglutinin-induced lymphocyte proliferation (Cossarizza et al., 1989), dose-dependent and time-dependent DNA single-strand and double-strand breaks (Ivancsits, Diem, Jahn, \& Rüdiger, 2003). Many studies were focused on radiofrequency (RF) fields, in particular fields produced by mobile or cellular phones which are a fundamental component of modern telecommunications. RF waves are electromagnetic fields usually characterized by frequencies between $30 \mathrm{kHz}$ and $300 \mathrm{GHz}$ (Zamanian \& Hardiman, 2005). Some causes due to RF energy may be biological effects (proportional to the rate of energy absorption), the heating of human tissues or tissue damages, caused by exposure to high RF energy levels (Zamanian \& Hardiman, 2005). Many investigations were performed over the last two decades to assess if RF fields may be a potential health risk: however, no adverse health effects were definitely established caused by mobile phones (European Commission, 2005; Scientific Committee on Emerging and Newly Identified Health Risks, 2007; WHO, 2011). About short term effects, the tissue heating is the principal mechanism of interaction between RF energy and the human body (WHO, 2010). The energy is absorbed by the skin and the other superficial tissues, giving a negligible temperature rise in the brain or the other parts of the body. However, no consistent evidence of adverse health effects from exposure to RF fields was defined at levels below those that cause tissue heating (International Commission on Non-Ionizing Radiation Protection, 2009). About long-term effects, they are very difficult to be identified and epidemiological studies can only assess those cancers that become evident within shorter time periods (WHO, 2010). Results of animal studies didn't show increased cancer risk for long-term exposure to RF fields. The effects of RF waves 
were also investigated on blood parameters and behavioral changes of rats, obtaining that the frequency is too low to get the resonance effects (Korpinar, Kalkan, Morgul, Birman, \& Hacibekiroglu, 1998). Investigations on possible cancer onset were an important research branch which may identify a critical effect of electromagnetic fields. Results are often contradictory also in this research field (Belpomme, Irigaray, \& Hardell, 2008; Haider T., Knasmueller, Kundi \& Haider M., 1994; Hardell \& Sage, 2008). However, IARC (International Agency for Research on Cancer) classified as Group 2B the RF electromagnetic fields, a category used when a causal association is credible, but when chance, bias or confounding cannot be excluded (WHO, 2010). The majority of the RF studies were focused on mobile phone frequencies, while also other RF frequencies may be an important and possible electromagnetic source which may give adverse health effects for humans (WHO, 2010). This paper describes a part of a multidisciplinary research on the possible effects of an important range of RF electromagnetic fields on man. In fact, man is always exposed to RF electromagnetic fields in the $30-300 \mathrm{MHz}$ range, which are typical of broadcasting radio and television communications. Thus, an investigation was carried out by an experimental facility which was built for exposing thymic cell cultures to the mentioned RF electromagnetic fields. Thymic cell cultures were chosen because their alterations are generally an index of cancerogenesis. The experimental facility was made by a climatic room, a control unit and a RF generating system. The RF generating system is made by a $144 \mathrm{MHz}$ transmitter connected to a condenser by a coaxial cable. A $144 \mathrm{MHz}$ frequency was chosen for the exposition tests because it is a typical frequency for radio amateur communications and it is intermediate between broadcasting radio and TV frequencies. Exposition tests were carried out for three and six hours; the electromagnetic field intensity into the cell cultures was simulated by a numerical code. Exposed and not-exposed cultures were analysed after the tests. This paper focuses on the analysis of the thermophysical properties of the cultures (density, viscosity, specific heat). The analysis was carried out in order to verify if the exposition induced alterations of such properties. Besides, other branches of this research verified possible variations in the biomedical properties of the cultures (Consorzio IPASS, 2010).

\section{The Experimental Facility}

The experimental facility was constituted by a climatic room, the RF generating system and a control unit. The control unit allowed the control of temperature, humidity and $\mathrm{CO}_{2}$ concentration to standard life condition for the cell cultures (i.e. temperature $=37^{\circ} \mathrm{C}$, humidity $=74 \%, \mathrm{CO}_{2}$ concentration $=5 \%$ ). Thus, the control unit is characterized by three inputs and three outputs. Three sensors (temperature, humidity and $\mathrm{CO}_{2}$ concentration) are connected to the control unit inputs; three actuators (electric resistors for temperature control, a vapour generator for humidity control, a pipe connected to a $\mathrm{CO}_{2}$ bottle for $\mathrm{CO}_{2}$ concentration control) are connected to the control unit outputs. The climatic room was designed to avoid anomalies in the electromagnetic field concentration. Thus, it was built in plastic material (polystyrene), which is transparent to $144 \mathrm{MHz}$ electromagnetic fields. The climatic room was constituted by three boxes (Figure 1 and Figure 2):

- Control box: it contains the actuator for $\mathrm{CO}_{2}$ control (a Lutron power interface unit connected to an EV SMC electrovalve) and the sensors for temperature, humidity and $\mathrm{CO}_{2}$ measurements. The sensors are a psychrometer (by Gefran, for temperature and humidity measurements) and a linearized $10 \% \mathrm{NDIR} \mathrm{CO}_{2}$ data acquisition card (by Tecnosens, see Figure 3).

- Actuator box: it contains the electrical resistors for temperature control and a vapour generator for humidity control. They are connected to a HT-3005 unit (by Lutron) for the temperature and humidity control.

- Measurement box: it contains only the not exposed cell cultures (which are shielded by a sinterized nickel box), the exposed cultures and the RF generating system; in this way, the cultures are not subjected to the electromagnetic radiations due to sensors and actuators placed in the control and in the actuator boxes.

The three boxes were connected to each other by plastic pipes. Fans were used to maintain uniform air conditions. 


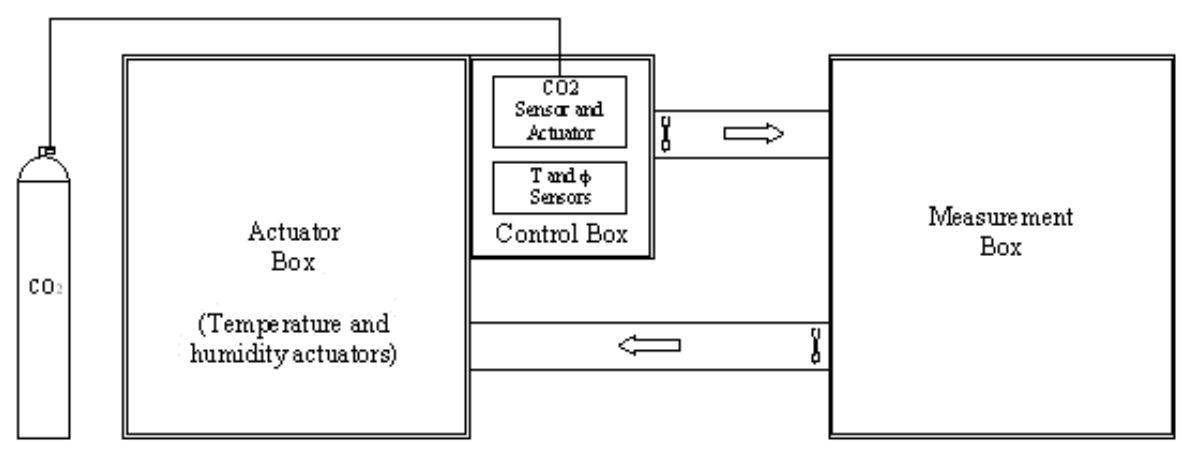

Figure 1. Climatic room scheme

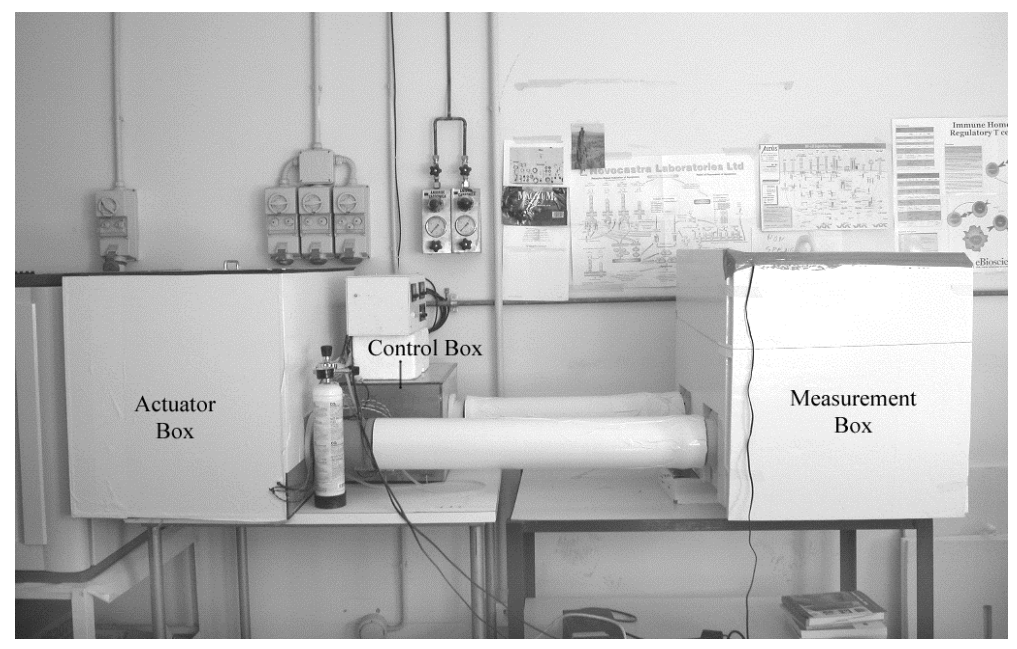

Figure 2. Picture of the climatic room

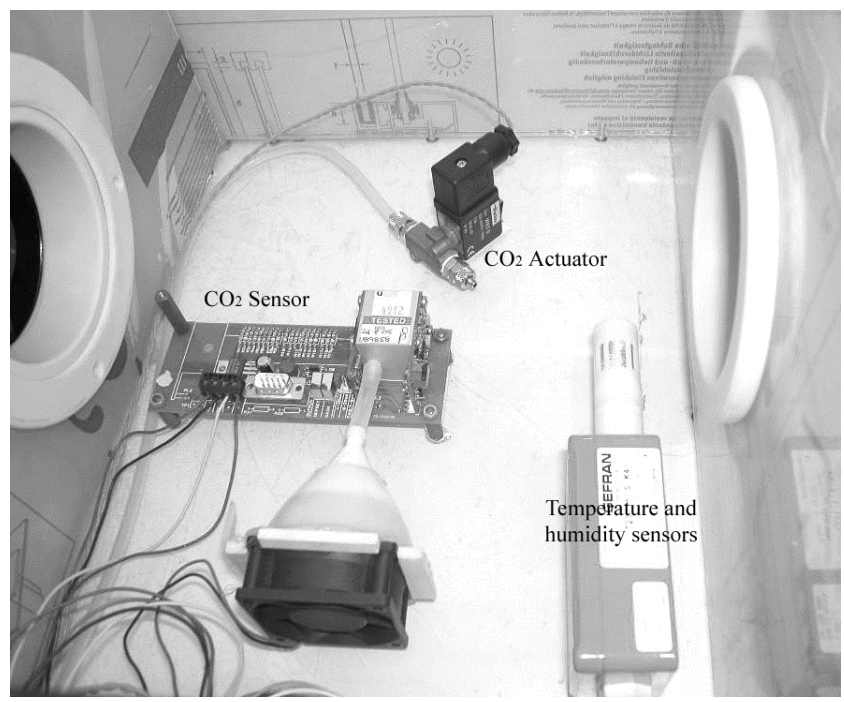

Figure 3. The control box

The RF generating system is constituted by a $144 \mathrm{MHz}$ transmitter connected to a condenser by a coaxial cable. The dimensions of the condenser plates are $10 \mathrm{~cm} \times 10 \mathrm{~cm} \times 1 \mathrm{~mm}$. The condenser plates are separated by air. The distance between the condenser plates is $2 \mathrm{~cm}$ (Figure 4). 


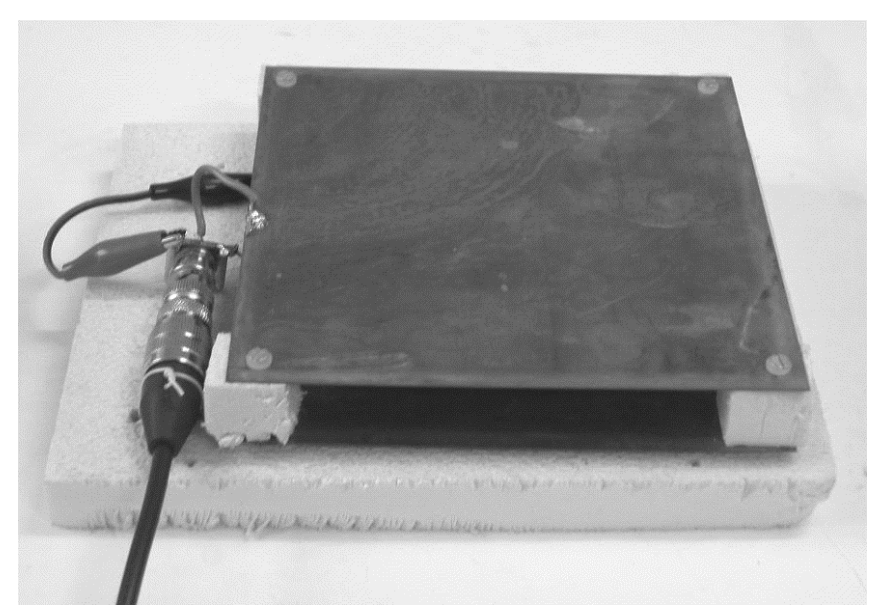

Figure 4. The condenser

\section{The Experimental Tests}

In vitro experiments were carried out on thymic cells obtained from $\mathrm{C} 3 \mathrm{H}$ rat thyme. The rats were 3-4 weeks aged of both the male and female sexes. They were obtained in single cells suspension after centrifugation (1200 $\mathrm{rpm}$ for $10 \mathrm{~min}$ ), washing and resuspension in a RPMI1640 culture medium containing 5\% concentration fetal bovine serum. Live cells were counted by a blood cytometer and diluted at a $2 \times 10^{6}$ cells $/ \mathrm{ml}$ concentration in cultures two-well plates. Two kinds of cultures were placed into the climatic room where standard climatic conditions were kept uniform and stable:

- $\quad$ exposed cells: their two-well plates were installed between the RF condenser plates (see Figure 5);

- $\quad$ not-exposed cells: their two-well plates were inserted into a sinterized nickel box characterized by high electromagnetic insulation (see Figure 6).

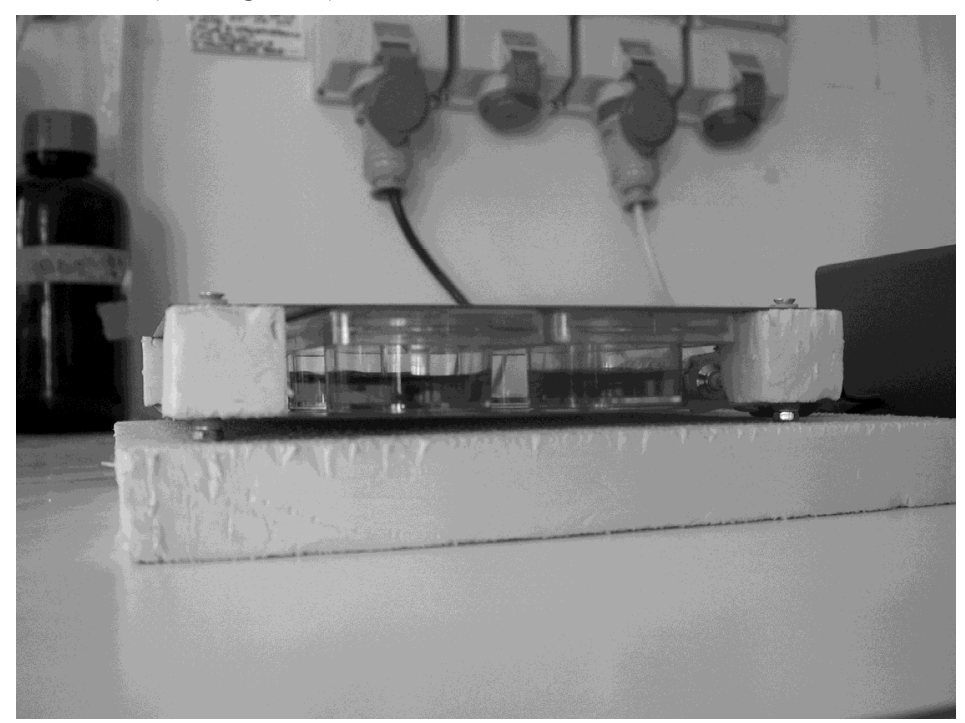

Figure 5. Cultures to be exposed in the condenser plates 


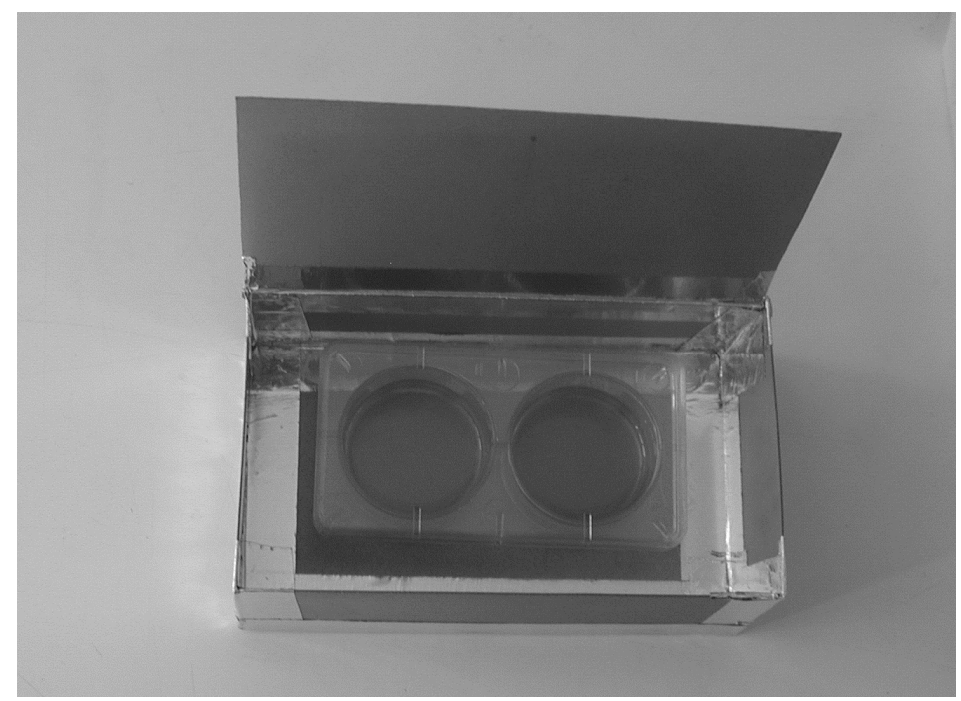

Figure 6. Not exposed cultures in the sinterised nickel box

A calibration campaign was carried out before each test in order to verify that standard climatic conditions are maintained in the measurement room. Stable standard conditions were obtained after two hours from the climatic room start-up. Air velocity and illuminance were also measured in the measurement room: their average values were respectively $0.05 \mathrm{~m} / \mathrm{s}$ and 17 lux. Two kinds of exposition tests were carried out:

- $\quad$ three hours exposure to $144 \mathrm{MHz}$ electromagnetic fields;

- Six hours exposure to $144 \mathrm{MHz}$ electromagnetic fields.

Ten tests were carried out for each condition.

Simulations were carried out from another Research Unit by a numerical code in order to identify the intensity of the electromagnetic fields to which the cultures were exposed. CST Microwave Studio was used as simulation software. $500 \mathrm{~mW}$ is the electromagnetic power which feeds the condenser by the $144 \mathrm{MHz} \mathrm{RF}$ transmitter. Simulation results show that the cell cultures are averagely exposed to a $0.6 \mathrm{~W} / \mathrm{m}^{3}$ power density (Vegni, Toscano, Bilotti, \& Sapia, 2006).

\section{Results and Discussion}

Not exposed and exposed cultures were inserted after the tests into a commercial climatic room (Mazzali Climatest C 330 G5) where standard life conditions are maintained. Thermophysical properties were measured for not exposed and exposed cultures.

Viscosity was measured by an Ubbelohde viscosimeter (calibration constant $\mathrm{Cs}=0.03347 \cdot 10^{-6} \mathrm{~m}^{2} / \mathrm{s}^{2}$ ). Measurements were carried out into the Mazzali climatic room at $37^{\circ} \mathrm{C}$ and high humidity $(74 \%)$ conditions (Figure 7). 


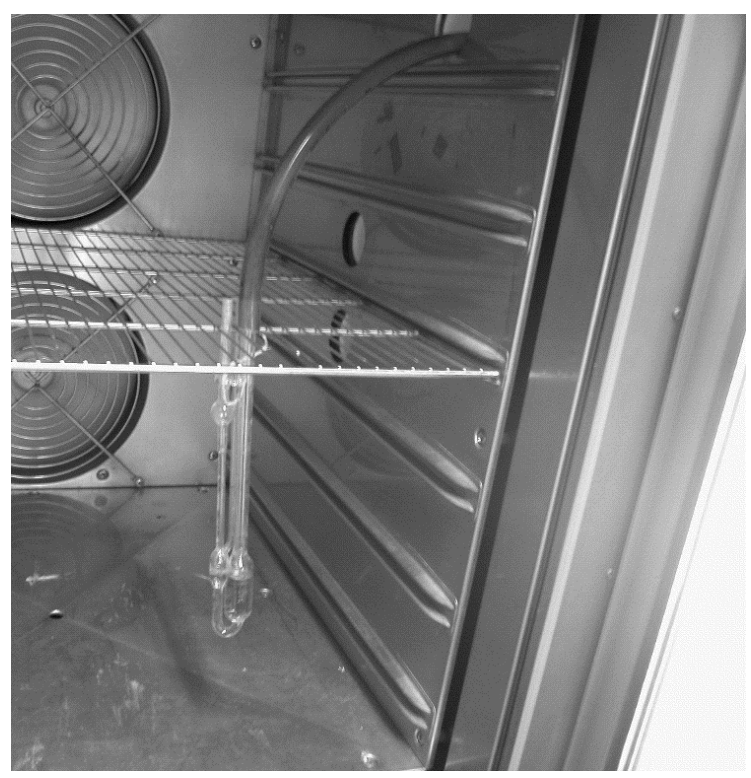

Figure 7. Picture of the viscosity measurements

Average measured kinematic viscosities were obtained as follows:

- not exposed cultures: $v=0.84610^{-6} \mathrm{~m}^{2} / \mathrm{s}\left(\right.$ standard deviation $\left.=0.03310^{-6} \mathrm{~m}^{2} / \mathrm{s}\right)$;

- 3-hours exposed cultures: $v=0.90810^{-6} \mathrm{~m}^{2} / \mathrm{s}$ (standard deviation $=0.00910^{-6} \mathrm{~m}^{2} / \mathrm{s}$ );

- 6-hours exposed cultures: $v=0.90110^{-6} \mathrm{~m}^{2} / \mathrm{s}$ (standard deviation $=0.02310^{-6} \mathrm{~m}^{2} / \mathrm{s}$ ).

A slight viscosity increase was measured after the exposure. However, it was expected that electromagnetic fields locally increase the culture temperature (Zamanian \& Hardiman, 2005): an effective variation is attested if a viscosity decrease occurred after the exposure. Furthermore, the obtained increase was lower than measurement errors. Thus, the previous assertions determined that the viscosity is not affected by the exposure at $144 \mathrm{MHz}$ electromagnetic fields in the tested conditions.

Density measurements were carried out by a precision weighing scale and a graduated container where the exposed and not-exposed cultures were inserted after the exposition tests. Measurements were carried out in the Mazzali climatic room at $37^{\circ} \mathrm{C}$ and high humidity (74\%) conditions. Average measured densities were obtained as follows:

- $\quad$ not exposed cultures: $\rho=1009.50 \mathrm{~kg} / \mathrm{m}^{3}$ (standard deviation $=3.50 \mathrm{~kg} / \mathrm{m}^{3}$ );

- $\quad$ 3-hours exposed cultures: $\rho=999.00 \mathrm{~kg} / \mathrm{m}^{3}$ (standard deviation $\left.=4.15 \mathrm{~kg} / \mathrm{m}^{3}\right)$;

- $\quad$ 6-hours exposed cultures: $\rho=996.67 \mathrm{~kg} / \mathrm{m}^{3}$ (standard deviation $\left.=3.32 \mathrm{~kg} / \mathrm{m}^{3}\right)$;

Thus, also density is not affected by the exposition to $144 \mathrm{MHz}$ electromagnetic fields.

Specific heat was measured by a calorimeter Setaram model C 80 Calvet.

Measurements were carried out in the temperature range of $35-40^{\circ} \mathrm{C}$ which is the maximum range for which cells may live without anomalies. Table 1 reports average results for exposed and not exposed cultures. Also specific heat was not affected by electromagnetic fields exposition. 
Table 1. Measured specific heat of not exposed and exposed cultures

\begin{tabular}{cccc}
\hline $\mathrm{T}\left({ }^{\circ} \mathrm{C}\right)$ & $\begin{array}{c}\text { Not exposed } \\
\mathrm{Cp}\left(\mathrm{kJ} /\left(\mathrm{kg}^{\circ} \mathrm{K}\right)\right.\end{array}$ & $\begin{array}{c}\text { 3-hours exposed } \\
\mathrm{Cp}\left(\mathrm{kJ} /\left(\mathrm{kg}{ }^{\circ} \mathrm{K}\right)\right.\end{array}$ & $\begin{array}{c}\text { 6-hours exposed } \\
\mathrm{Cp}\left(\mathrm{kJ} /\left(\mathrm{kg}{ }^{\circ} \mathrm{K}\right)\right.\end{array}$ \\
\hline 35.0 & 3.9484 & 3.9915 & 3.9794 \\
35.5 & 3.9777 & 3.9924 & 3.9811 \\
36.0 & 3.9836 & 4.0171 & 3.9945 \\
36.5 & 3.9840 & 3.9915 & 3.9949 \\
37.0 & 3.9940 & 3.9991 & 4.0003 \\
37.5 & 4.0158 & 4.0254 & 4.0175 \\
38.0 & 4.0204 & 4.0267 & 4.0258 \\
38.5 & 4.0288 & 4.0338 & 4.0271 \\
39.0 & 4.0526 & 4.0434 & 4.0476 \\
39.5 & 4.0840 & 4.0844 & 4.0727 \\
40.0 & 4.0957 & 4.1129 & 4.0970 \\
\hline
\end{tabular}

\section{Conclusions}

Thermophysical properties of thymic cell cultures exposed to RF electromagnetic fields were investigated. The objective was to investigate the possible effects of $144 \mathrm{MHz}$ electromagnetic fields on human health. Thus, an experimental facility was built: exposed and not exposed thymic cell cultures were characterized in terms of viscosity, density and specific heat. Results showed that the thermophysical properties of thymic cell cultures were not modified by $144 \mathrm{MHz}$ electromagnetic fields in the used test conditions and configuration (short term exposures). Besides, biomedical analyses developed by the Clinical and Medical Department of the University of Perugia showed that also biomedical pathways (such as Ras, p53, BCL-2) and cellular processes such as apoptosis and proliferation are not modified by the short term exposure (Consorzio IPASS, 2010).

\section{References}

Atay, T., Aksoy, B. A., Aydogan, N. H., Baydar, M. L., Yildiz, M., \& Ozdemir, R. (2009). Effect of electromagnetic field induced by radio frequency waves at 900 to $1800 \mathrm{MHz}$ on bone mineral density of iliac bone wings. J Craniofacial Surgery, 20, 1556-1560. http://dx.doi.org/10.1097/SCS.0b013e3181b78559

Belpomme, D., Irigaray, P., \& Hardell, L. (2008). Electromagnetic fields as cancer-causing agents. Environmental Research, 107, 289-290. http://dx.doi.org/10.1016/j.envres.2008.01.017

Consorzio IPASS. (2010). Indagine sperimentale su fenomeni di cancerogenesi indotta da campi elettromagnetici su cellule bersaglio e materia vivente in ambiente controllato. Proceedings of Workshop ISPRA 10 luglio 2007. Retrieved from http://www.agentifisici.isprambiente.it/normativa-cem/normativa-regionale/cat_view/70-documenti-cem/

Cossarizza, A., Monti, D., Bersani, F., Cantini, M., Cadossi, R., Sacchi, A., \& Franceschi, C. (1989). Extremely low frequency pulsed electromagnetic fields increase cell proliferation in lymphocytes from young and aged subjects. Biochemical and Biophysical Research Communications, 160, 692-698. http://dx.doi.org/10.1016/0006-291X(89)92488-1

European Commission, Health and electromagnetic fields. (2005). EU-funded research into the impact of electromagnetic fields and mobile telephones on health. Retrieved from http://ec.europa.eu/health/archive/ph_determinants/environment/emf/brochure_en.pdf

Haider, T., Knasmueller, S., Kundi, M., \& Haider, M. (1994). Clastogenic effects of radiofrequency radiation on chromosomes of Tradescantia. Mutation Research, 324, 65-68. http://dx.doi.org/10.1016/0165-7992(94)90069-8

Hardell, L., \& Sage, C. (2008). Biological effects from electromagnetic field exposure and public exposure standards. Biomed. Pharmacother, 62, 104-109. http://dx.doi.org/10.1016/j.biopha.2007.12.004

Heinrich, S., Thomas, S., Heumann, C., Von Kries, R., \& Radon, K. (2011). The impact of exposure to radio 
frequency electromagnetic fields on chronic well-being in young people - a cross-sectional study based on personal dosimetry. Environment International, 37, 26-30. http://dx.doi.org/10.1016/j.envint.2010.06.008

Hocking, B., Gordon, I. R., Grain, H. L., \& Hatfield, G. E. (1996). Cancer incidence and mortality and proximity to TV towers. Medical Journal of Australia, 165, 601-605.

International Commission on Non-Ionizing Radiation Protection. (2009). Exposure to high frequency electromagnetic fields, biological effects and health consequences (100 kHz-300 GHz). Retrieved from http://www.icnirp.de/documents/RFReview.pdf

Ivancsits, S., Diem, E., Jahn, O., \& Rüdiger, H. W. (2003). Intermittent extremely low frequency electromagnetic fields cause DNA damage in a dose-dependent way. International Archives of Occupational and Environmental Health, 76, 431-436. http://dx.doi.org/10.1007/s00420-003-0446-5

Khalid, M., Mee, T., Peyman, A., Addison, D., Calderon, C., Maslanyj, M., \& Mann, S. (2011). Exposure to radio frequency electromagnetic fields from wireless computer networks: duty factors of Wi-Fi devices operating in schools. Progress in Biophysics and Molecular Biology, 107, 412-420. http://dx.doi.org/10.1016/j.pbiomolbio.2011.08.004

Korpinar, M. A., Kalkan, M. T., Morgul, A., Birman, H., \& Hacibekiroglu, M. (1998). The effect of electromagnetic field with a frequency of $144 \mathrm{MHz}$ on the blood parameters and behavior of rats. Proceedings of the 1998 2nd International Conference Biomedical Engineering Days, 82-84, Istanbul, 20-22 May 1998. http://dx.doi.org/10.1109/IBED.1998.710575

National Council on Radiation Protection and Measurements. (1986). Biological Effects and Exposure Criteria for Radio Frequency Electromagnetic Fields. NCRP Report 86, Bethesda, MD.

Noriega-Luna, B., Sabanero, M., Sosa, M., \& Avila-Rodriguez, M. (2011). Influence of pulsed magnetic fields on the morphology of bone cells in early stages of growth. Micron, 42, 600-607. http://dx.doi.org/10.1016/j.micron.2011.02.005

Rosai, J., \& Sobin, L. H. (1999). Histological typing of tumors of the thymus. WHO International Histological Classification of Tumors, Rosai J Sobin LH eds., 1-65.

Scientific Committee on Emerging and Newly Identified Health Risks. (2007). Possible effects of Electromagnetic Fields (EMF) on Human Health. SCENIHR 16th plenary report. Retrieved from http://ec.europa.eu/health/ph_risk/committees/04_scenihr/docs/scenihr_o_007.pdf

Thomas, S., Heinrich, S., Von Kries, R., \& Radon, K. (2010). Exposure to radio-frequency electromagnetic fields and behavioural problems in Bavarian children and adolescents. European Journal of Epidemiology, 25, 135-141. http://dx.doi.org/10.1007/s10654-009-9408-x

Vegni, L., Toscano, A., Bilotti, F., \& Sapia, C. (2006). Attività di Ricerca sull'inquinamento Elettromagnetico Ambientale Indoor di Reti Wireless Svolta nel 2005 dall'unità di Roma TRE del CIRIAF. Proceedings of $6^{\circ}$ Congresso Nazionale CIRIAF, Perugia, 7-8 April 2006.

World Health Organization. (1993). Electromagnetic Fields (300 Hz to $300 \mathrm{Ghz}$ ). Environmental Health Criteria 137, Geneva, Switzerland.

World Health Organization. (2010). Research Agenda for Radiofrequency Fields. Retrieved from http://whqlibdoc.who.int/publications/2010/9789241599948_eng.pdf

World Health Organization. (2011). Electromagnetic fields and public health: mobile phones. Retrieved from http://www.who.int/mediacentre/factsheets/fs193/en/

Zamanian, A., \& Hardiman, C. (2005). Electromagnetic Radiation and Human Health: A Review of Sources and Effects. High Frequency Electronics Copyright (C) 2005 Summit Technical Media, 16-26. 